\title{
Coautoria urbana e quarentena: relações pessoa-cidade na pandemia do novo coronavírus
}

\author{
Urban co-authorship and quarantine: \\ person-city relations in the new coronavirus pandemic
}

Gabrielle Queiroz da Rocha [I]

\begin{abstract}
Resumo
Cidades vazias e nem tão vazias. Pessoas isolam-se, outras continuam explorando a cidade por necessidade ou por não temerem/acreditarem no perigo. A pandemia da Covid-19 mudou parte do mundo, e este artigo busca investigar novas perspectivas do conceito de coautoria urbana (Rocha, 2019) ante a crise. Essas perspectivas, pautadas por modificações nas relações dos cidadãos com a cidade, também transpassam a latência das desigualdades social e racial, gerando respostas das pessoas. Assim, busca-se compreender como as apropriações urbanas funcionaram e se organizaram durante o isolamento social, no momento de reabertura, e quais perspectivas do pós-pandemia, de forma ainda genérica. Este artigo se apoia em autores como Lefebvre (2008) e Foucault (1987), dentre outros, na observação do cotidiano e em entrevistas.
\end{abstract}

Palavras-chave: quarentena; coautoria urbana; isolamento; pandemia; vigilância.

\begin{abstract}
Empty and not so empty cities. People isolate themselves, others continue to explore the city because they need it or because they do not fear/ believe in the danger. The Covid-19 pandemic has changed part of the world and this paper investigates new perspectives of the concept of urban co-authorship (Rocha, 2019) in the face of the crisis. These perspectives, guided by changes in citizens' relations with the city, also cross the latency of social and racial inequalities, generating responses from people. Thus, we seek to understand how urban appropriations operated and were organized during social isolation and at the reopening, as well as the perspectives for the post-pandemic period, still in a generic way. This paper is supported by authors such as Lefebvre (2008) and Foucault (1987), among others, by the observation of daily life and by interviews.
\end{abstract}

Keywords: quarantine; urban co-authorship; isolation; pandemic; surveillance. 


\section{Introdução: metodologia de análise}

0 presente artigo foi desenvolvido mesclando a pesquisa sobre o conceito de coautoria urbana, que vem sendo desenvolvido desde 2017, e suas modificações e atualizações a partir das situações que a pandemia da Covid-19 impôs às cidades. A metodologia escolhida para o estudo foi inicialmente: a leitura de autores que dão suporte à construção do citado conceito, de outros que auxiliam na atualização do conceito no contexto pandêmico e de notícias que tratam de novas situações urbanas surgidas ao longo da pandemia. O leque de autores estudados não foi extenso para que os selecionados fossem mais aprofundados, tendo quantidade e qualidade suficientes para embasar as outras ações metodológicas, a serem colocadas adiante.

As leituras, então, foram unidas à pesquisa prévia do conceito de coautoria urbana e à observação e análise do cotidiano a partir de vivências pessoais, ${ }^{1}$ através da ótica do urbanismo. Entretanto, surgiu a necessidade de ampliar o recorte do contexto de análise, tanto físico quanto social (relacionado ao sair para trabalhar/não sair), para que o artigo não se limitasse à romantização do "trabalhar/ ficar em casa" nem ao cotidiano de pessoa moradora de favela. Dessa forma, um terceiro movimento foi a elaboração, a convocação (através das redes sociais e do acionamento de contatos) e a realização de entrevistas ${ }^{2}$ on-line com algumas pessoas que precisavam sair para trabalhar durante o período do fechamento do comércio, sendo elas moradoras de bairros das zonas Oeste, Sul e Norte do
Rio de Janeiro que se deslocavam através de diferentes meios de transporte. As entrevistas foram feitas com o intuito de identificar as situações de coautoria urbana a partir das próprias pessoas e de suas diferentes perspectivas diante da situação, seja por conta de seus bairros de moradia, seja por conta de suas formas de perceberem a cidade.

Por fim, foi feita uma análise geral de todo o material obtido, resultando na percepção das novas camadas de coautores urbanos e no desenvolvimento de ideias sobre o futuro pós-pandêmico, permeando a vigilância em contraponto à subversão nas apropriações urbanas.

\section{0 que é coautoria urbana}

As cidades são constituídas de matéria estática - seus edifícios, ruas, calçadas, etc. - e de seres que fluem por elas, dando-Ihes vida e tornando-as dinâmicas e reais. Entretanto, o estático vem sendo priorizado ao longo da história justamente por uma parcela desses seres: os que detêm algum poder e que possuem maior distanciamento da vivência mais entregue e palpável da cidade. A priorização ocorre, por exemplo, através da implementação de projetos espetaculares e remocionistas, em detrimento da população menos favorecida, ou seja, de pessoas que fluem e vivem o cotidiano urbano de maneira mais franca e próxima da realidade. Essa parcela, em contrapartida, juntamente com outros cidadãos, apropria-se da cidade de diversas formas, seja através de usos subversivos ou corriqueiros, seja através de maneiras outras que nem sempre são bem-aceitas por outras camadas da população. 
A partir dessa percepção que reflete sobre as existências dos seres e seus conflitos no meio urbano, é possível traçar o conceito de "coautoria urbana", que defende que a autoria da cidade não se concentra somente nos que detêm algum tipo de poder, seja ele econômico ou político, e sim que ela é compartilhada entre eles e os cidadãos que dela se apropriam. Esta apropriação pode ser feita tanto pela forma na qual o espaço foi pensado originalmente quanto subvertida, e esta subversão pode ser tomada pelos detentores de poder como algo negativo, o que gera os citados conflitos.

Jacobs (2011) comenta que a diversidade construída pelas cidades "[...] repousa no fato de que nelas muitas pessoas estão bastante próximas e elas manifestam os mais diferentes gostos, habilidades, necessidades, carências e obsessões" (p. 161). Dessa forma, para entender a coautoria, é preciso levar em consideração que existem diversas camadas de coautores urbanos que, divididas entre o topo e a base, são organizadas conforme suas formas de apropriação da cidade e constituem diversos atores. Assim, alguns atores se apropriam da cidade para lazer, para deslocamento, para trabalho, para reativação de algum espaço, para um momento de estar, dentre outras possibilidades. E é justamente quando as diferenças se cruzam que se visualiza uma cidade bricolada, repleta de dinâmicas próprias.

Raban (1974) escreve: "Decida quem você é, e a cidade mais uma vez vai assumir uma forma fixa ao seu redor" (apud Bresciani, 2017, p. 104). Ou seja, ao fazer parte da cidade, o cidadão é seu autor, e ele é a própria cidade; e o anseio por ser, estar e apropriar-se dela existe, mesmo que inconscientemente.
Entretanto, com a pandemia do novo coronavírus, esse anseio começa a surgir em algumas dessas camadas de cidadãos, mas, dependendo de suas condições de moradia e de trabalho, além das sociais e financeiras, as situações de coautoria urbana são desenhadas de formas muito distintas.

\section{A quarentena}

A quarentena evidenciou a necessidade do âmago em estar na cidade, em vivê-la e apropriar-se dela, mesmo que da forma mais simples. A cada dia que passava, as expectativas sobre o dia dessa apropriação aumentavam. Projetos mentais sobre lugares para ir, encontros marcados com amigas e amigos, o trabaIho, a faculdade, a escola, os encontros familiares, boa parte dos planos futuros girava em torno da apropriação urbana, seja como lazer ou como deslocamento. Mas, enquanto esse futuro não chegava, um turbilhão de sensações e reflexões com relação ao meio urbano se colocou, mesmo que de forma inconsciente, gerando a angústia urbana, aqui definida como o medo ao sair e explorar o meio urbano, mesmo que somente ao deslocar-se por ele, ou como a tristeza de estar em quarentena e ter vontade de apropriar-se da cidade. Sentimentos opostos e complementares ao mesmo tempo: medo de fazer e anseio por fazer. Ambos podem aflorar separadamente ou juntos em cada cidadão, estando em quarentena ou não. E essa angústia urbana é, portanto, a grande base do que é ser coautor urbano em uma pandemia. 


\section{Depoimentos durante o fechamento do comércio/isolamento}

Como forma de começar a desenhar o panorama da coautoria urbana diante da cidade que vive a pandemia da Covid-19, são apresentados, a seguir, alguns relatos de moradores da cidade do Rio de Janeiro, coletados a partir de entrevistas. Essas pessoas precisaram sair para trabalhar, nos primeiros meses de fechamento do comércio, e são moradoras de bairros diversos.

\section{Depoimento $1^{3}$}

Essa depoente mora no Tanque (Jacarepaguá) e trabalha em um banco na praça Seca, diariamente. Utiliza BRT, sistema de transporte coletivo, e não parou de trabalhar em nenhum momento. $\mathrm{O}$ banco esteve com filas enormes, e ela trabalhou muito mais - todos os dias fazia hora extra. Como lida com o público, percebia que as pessoas iam ao banco mesmo sem ser por extrema necessidade. Por isso, ela acredita ser errado o banco ter sido considerado serviço essencial para todos, quando deveria ter sido somente para os idosos, que têm mais dificuldade com tecnologias. Ela trabalhou com medo, mas, como se tornou rotina, acostumou-se, e não saia para mais nenhum outro lugar. Está revoltada com a situação das pessoas e triste com relação ao País.

A primeira semana foi assustadora para ela, com ruas vazias e BRT vazio. Com o passar do tempo, sentiu que as pessoas não estavam com consciência ou se importando, aparentemente. Um mês depois, percebeu as ruas cheias, o BRT completamente lotado, tanto na ida quanto na volta para a casa. Segundo ela, muitos não estavam trabalhando, acreditavam estar de férias e "brincavam" com a situação, não aguentando permanecer em casa.
Via idosos em praças, a rua lotada, as pessoas andando, conversando, e não sentia alarde. Ela comenta que, no BRT, muitos estavam sem máscara e que em nenhum dia viu fiscalização. Nem os tradicionais vendedores ambulantes do transporte estavam usando máscara. Ela comenta ficar em dúvida se os brasileiros são ingênuos por agirem assim, e se apega aos casos de solidariedade que vê na internet - o oposto do que vê no cotidiano da rua.

\section{Depoimento 2}

A segunda depoente mora em Gardênia Azul, trabalha em Madureira, em escritório, e utiliza todos os dias van e BRT. Comenta que corre o risco, mas precisa ir trabalhar porque precisa levar o alimento para casa. 0 primeiro medo é ser contaminada, e o segundo é de que a contaminação seja fatal. Mas o maior medo, ainda, é o de ser contaminada e transmitir para o ente querido com quem vive. Segundo ela, é muito tenso acordar cedo, chegar na condução e ver um indivíduo que não se cuida, sem máscara, espirrando. Isso aconteceu muitas vezes e gerou grande paranoia. Ela utiliza álcool, desequilibra-se dentro do BRT, para não tocar em nada, e ainda precisa lidar com pessoas que não estão respeitando.

Uma companheira de trabalho estava com tosses e foi aconselhada a procurar um médico, até porque o espaço e os objetos no trabalho eram compartilhados. Somente quando insistiram, ela fez o teste, que indicou resultado positivo para a Covid-19. A partir daí, a entrevistada precisou separar seus objetos pessoais em casa e se isolar. Para ela, algumas pessoas têm sintomas e, para não serem demitidas ou ganharem menos, não se importam e continuam indo trabalhar. Assim, ela sentia que estava vivendo o tempo todo alerta 
e, quando chegava em casa, pensava: "já passei por mais um dia". O medo foi constante, principalmente por ser do grupo de risco. $\mathrm{Pa}$ ra ela, infelizmente, as pessoas não se cuidam nem se importam umas com as outras. Não acreditavam na gravidade e continuavam na cidade sem máscaras, sem pensarem nas pessoas de suas casas. Ela comenta que, se as pessoas tivessem de trabalhar, que deveriam fazê-lo com atenção e consciência. E, se fossem do grupo de risco, como ela, que redobrassem a atenção.

\section{Depoimento 3}

O terceiro depoente mora na favela Rio das Pedras (Jacarepaguá), trabalha em um escritório em Vila Isabel, mediante demanda, e utiliza ônibus, levando uma hora e vinte minutos no deslocamento. Saía com medo, por conta da "ausência da consciência alheia", e via, por a toda cidade, pessoas que deveriam estar em casa. Ele comenta que dentro do ônibus todos estavam de máscara, mas muitos não eram dos serviços essenciais. Sentia egoísmo por toda a parte, com pessoas indo para bares e festas. Acredita que "a ficha não havia caído" para muitas pessoas, que colocavam a si e as outras pessoas em risco.

\section{Depoimento 4}

A quarta depoente mora na Tijuca, trabalha na Freguesia, com fotografia, e utiliza carro por aplicativo, porque carrega objetos de valor, levando trinta minutos no percurso. Em algumas semanas, saía duas vezes, em outras, não saía. 0 carro sempre permanecia com vidro aberto, gerando mais tranquilidade que ônibus e metrô. Ela não teve medo, porque mentalizou que, se se monitorasse (não levar a mão ao rosto, lavar as mãos, usar álcool em gel), iria sentir-se no controle, e tudo permaneceria tranquilo.

Para ela, antes a cidade estava bem vazia e, quando saía, percebia que alguma coisa estava acontecendo, sentia estranhamento. Depois, percebeu tudo normal na rua, que estava cheia, com muitas pessoas não seguindo as medidas de proteção, quase um universo paralelo. Sua impressão era a de que em casa existia o perigo e na rua estava tudo normal. Veio, então, o autoquestionamento quanto a estar com paranoia, porque enxergava as pessoas agindo normalmente. Como saía com a máscara, não poderia fingir que não estava acontecendo nada, porque a máscara é visual, e, quando o uso de máscara se tornou obrigatório, viu as ruas mais cheias. Antes da máscara, ela percebia um menor volume de carros onde mora. Depois, o trânsito voltou a ser barulhento e normal, exceto à noite, quando a rua ficava vazia, sem carros e sem pessoas, com comércios fechando mais cedo. Ela sentia que a rua, mesmo que vazia, estava mais segura.

\section{Depoimento 5}

A quinta depoente mora em Copacabana e trabalha na Gávea, em escritório com sala ampla e sem atender pessoas. Desloca-se de carro e, no início da pandemia, levava entre doze e quinze minutos no percurso, porque não havia trânsito. Ela ia com uma colega de trabalho, porque ambas são vizinhas. Assim, ela convivia com as mesmas pessoas todos os dias, indo de duas a três vezes por semana no esquema de rodízio, e a sala permanecia quase vazia. Ela não sentia medo de ir ao trabalho, e sim de ir a lugares, como o mercado. A diferença que reparou nas ruas, em comparação ao 
período anterior, é que estavam muito vazias, mais que o normal. Não havia trânsito, mas ainda percebia algumas pessoas andando, em sua maioria de máscara. Para ela, as pessoas estavam mais silenciosas, mais fechadas e introspectivas, sensação reforçada pela máscara. Ela considerava estranho, triste e depressivo ir para a rua.

\section{O coautor urbano explora a cidade da pandemia}

A partir desses relatos e de observações, assim como de vivências pessoais, entende-se que a coautoria urbana na pandemia, durante o período de quarentena/fechamento do comércio, aconteceu de diferentes formas, dependendo das condições de vida e do pensamento dos cidadãos. A seguir, então, a coautoria urbana é organizada por grupos, conforme suas particularidades.

\section{Quarentena total}

A cidade foi território de exploração perigosa, sendo apropriada em momentos pontuais e somente para uso de serviços essenciais. 0 espaço público, portanto, foi utilizado apenas para deslocamentos rápidos, e não houve apropriação espontânea ou modificadora do uso. Aos mais preocupados, por exemplo, uma ida ao mercado pôde passar a ser "o momento", no sentido de este ser um dos únicos instantes de seu cotidiano no qual foi possível explorar a cidade e, ao mesmo tempo, "o momento", no sentido de este ser um ponto tenso, o momento de expor seu corpo ao perigo de contaminação que a cidade oferecia.

Figura 1 - Caminhada na rua com uso de máscara

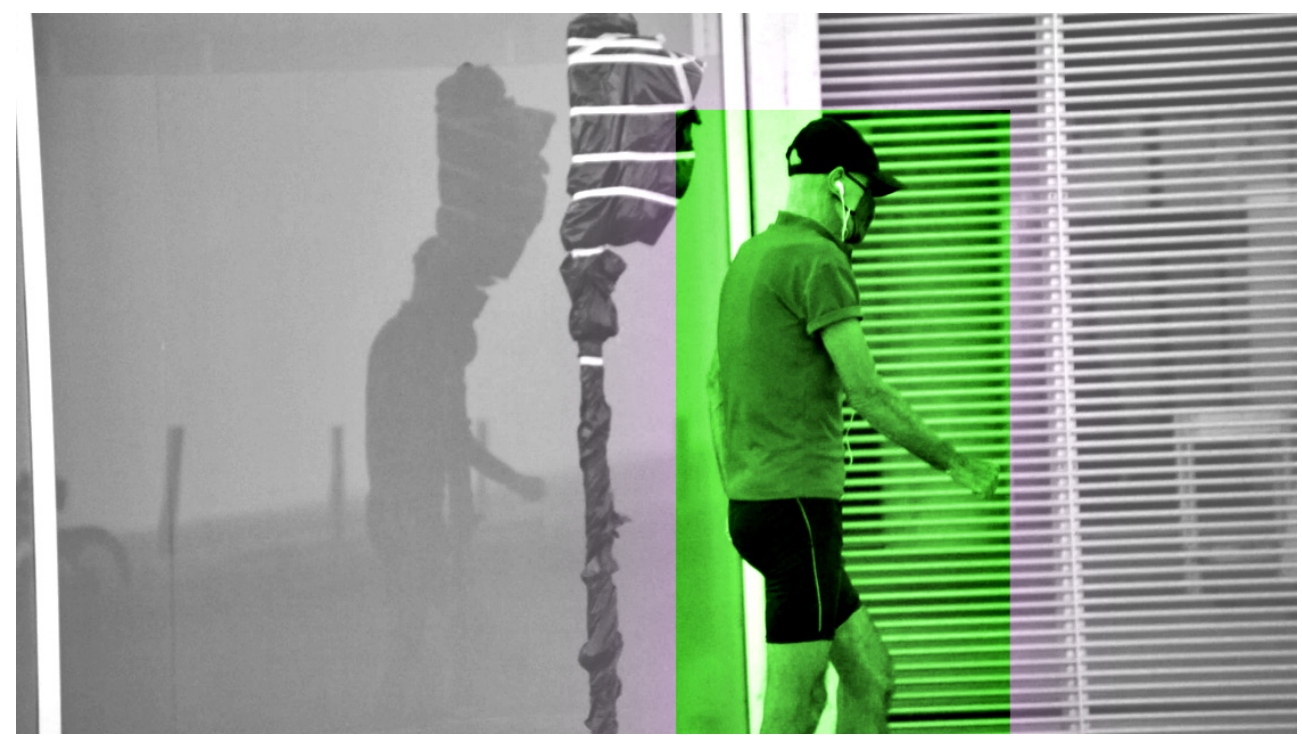

Fonte: autoral, 2020. 
Os que têm que sair - medo constante ou anestesia do cotidiano

Esse grupo precisou trabalhar fora de casa, seja nos serviços essenciais ou em outros locais que permaneceram funcionando. ${ }^{4}$ Parte dessas pessoas teve medo da saída, por conta do momento do deslocamento dentro do transporte público, ou da interação com os colegas de trabalho, e/ou com o público que atendem, especialmente por ser uma situação, se não cotidiana, quase cotidiana. Assim, o que antes era um ato mecânico cotidiano, como entrar em um ônibus, tornou-se uma angústia urbana. A preocupação de contaminação e morte foi grande, mas, para alguns, foi ainda maior a preocupação de carregar o vírus para casa e contaminar familiares. A cidade, então, foi espaço de tensão cotidiana, e sua livre apropriação também não aconteceu.

Uma parcela desse grupo pode ter se tornado anestesiada pelo cotidiano ou mesmo ter exercitado a mente para conseguir trabaIhar sem desesperos, segundo os relatos descritos. A anestesia do cotidiano é algo comum em qualquer esfera e não seria diferente nessa situação aqui descrita e analisada. Os trabaIhadores já anestesiados não se apropriaram da cidade de formas diferentes, além do deslocamento para o trabalho. Entretanto, esse deslocamento ocorreu de forma mais tranquila e menos desesperada que no grupo anterior. A angústia urbana, para esse grupo, foi leve ou nenhuma, e uma das razões para tal pode ter sido o uso da máscara. Parte dos relatos, além da observação pessoal, coloca que, a partir do momento em que o uso da máscara foi obrigatório, o fluxo de pessoas na rua aumentou. Além de ser visual, a máscara traz a sensação de segurança, e alguns provavelmente a entendem como uma autorização para poder sair pela cidade, mesmo que muitos ainda não a utilizassem na época das entrevistas.

\section{Grupo negacionista}

O grupo negacionista é, sem dúvidas, o mais complexo de compreensão. Esses coautores ignoraram as recomendações de distanciamento social e, para eles, a cidade continuou sendo território de exploração e apropriação. A coautoria urbana tornou-se, nesse grupo, ainda mais latente, porque a simples ocupação corporal do cidadão do espaço da rua a modificou completamente, justamente por ele não ter permissão para tal. Banhistas que insistiram em divertir-se na praia, pessoas que promoveram festas em ruas ou que permaneceram nas praças jogando ou interagindo com colegas... Os exemplos são muitos e ultrapassam as barreiras das zonas na qual a cidade do Rio de Janeiro é dividida. Aqui, mesmo que a apropriação em si não fosse subversiva (como sentar-se em um banco de praça que foi projetado para tal, ao invés de deitar-se nele, por exemplo), ela torna-se subversiva porque, naquele momento, qualquer uma era. E essa subversão, que sempre foi fundamental e interessante para um meio urbano vivo e pulsante, torna-se sua própria condenação.

A tensão da saída por parte dos que fizeram quarentena total foi ainda mais forte por esse ser o momento em que havia necessidade de cruzar ou interagir com os outros dois grupos. Além disso, observar a apropriação dos grupos negacionistas alimentou um sentimento de impotência ou mesmo de raiva, por recair como uma postergação para o fim da pandemia. Os que precisaram sair tiveram, 
em sua apropriação tímida, a convivência com os outros cidadãos que pertenciam também a essa camada, compartilhando o espaço e os sentimentos, seja de medo ou de condicionamento. E o sentimento de medo foi potencializado pela permanência dos negacionistas no meio urbano.

\section{Coautores pré-pandemia versus coautores na pandemia}

Com base nas camadas já identificadas por Rocha (2019) de coautores urbanos - cidadãos formais, marginalizados e ativistas urbanos -, procura-se também compreender como elas se comportam adiante da pandemia e do período de isolamento social. É importante salientar que os coautores mencionados previamente se distribuem ao longo das camadas trabalhadas a seguir, ou seja, em todas elas é possível encontrar diversas formas de enxergar o isolamento social e a quarentena. Por isso, aqui será exemplificado como a sua relação prévia com o espaço urbano se modificou de forma geral com a pandemia.

Cidadãos formais: no pré-pandemia, eles utilizavam o espaço da cidade para espera, deslocamento e/ou diversão, apropriando-se, da forma esperada ou não, como pessoas em lazer, turistas ou funcionários de empresas. No período de quarentena, esses coautores fizeram parte da parcela dos que puderam fazer home office, bem como se isolar. Ao mesmo tempo, dentro dessa camada existem atores que precisaram se arriscar, deslocando-se para o trabalho "formal", como serviços essenciais. Também existem cidadãos que ficaram desempregados e que, por essa razão, seguiram em casa ou na rua, em busca de emprego, e em filas na busca pelo auxílio emergencial do governo, ou mesmo que perderam as suas casas e precisaram se estabelecer nas ruas ou em ocupações. ${ }^{5}$

Cidadãos marginalizados: no pré-pandemia, a cidade era local de trabalho ou moradia para esses coautores, de forma que precisavam do espaço urbano para viver e sobreviver, criando muitas vezes subversões dos usos propostos, como camelôs e pessoas em situação de rua. Na pandemia, esses coautores muitas vezes formaram filas intermináveis em bancos na tentativa de receber o auxílio emergencial do governo, ${ }^{6}$ isso porque muitos não tinham o acesso à tecnologia que os permitiria fazer por métodos digitais ou por problemas de documentos, etc. Além disso, a rua continuou sendo território comum de ocupação, em que vários deles permaneceram vendendo produtos, mesmo que sem um ponto fixo. ${ }^{7}$ Dentro dessa camada, as pessoas em situação de rua permaneceram com sua ocupação do espaço urbano, agora com mais dificuldades por conta do risco de contaminação da doença.

Ativistas urbanos: no pré-pandemia, esses coautores buscavam ativar/reativar espaços da cidade, seja através de apropriações indicativas da existência do espaço, apropriações subversivas, ou estímulo à apropriação de outras pessoas, dentre outras possibilidades. Na pandemia, boa parte desses atores possuía consciência da necessidade de ficar em casa. A impossibilidade de intervenções e ações urbanas diretas movimentou a transmissão ao vivo pela internet de debates, shows, vídeos e festivais por parte desses atores, geralmente acompanhada por pedidos de ajuda para "vaquinhas", já que muitos deles não podiam continuar com seu trabalho; razão pela qual este seja provavelmente um dos últimos grupos 
Figura 2 - As constantes filas nas portas dos bancos na busca pelo auxílio emergencial do governo

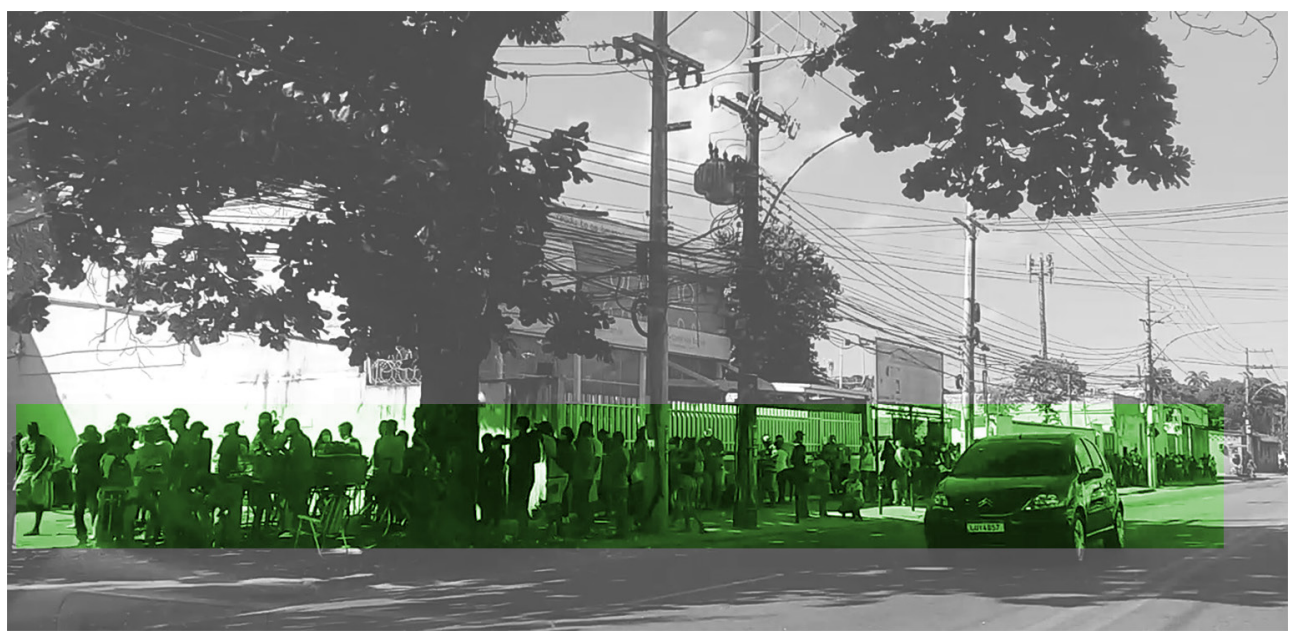

Fonte: autoral, 2020.

que retornará ao normal. Alguns desses atores também estão propondo (ou executando) microintervenções urbanas, como pequenas formas de melhoria dos espaços, especialmente após a reabertura.

Após a compreensão dessas múltiplas perspectivas sobre as formas de apropriação urbana, é possível esboçar uma ideia de como essa cidade funciona na pandemia de forma mais corriqueira e abrangente, para então serem trabalhadas questões mais pontuais.

\section{A afirmação da cidade-imagem}

Em postagem de uma rede social, tem-se a imagem aérea das calçadas na orla de Copacabana, com seus belíssimos desenhos de Burle
Marx, e os dizeres "Quando saem as pessoas, aparece a arte". Observa-se aí a consolidação da ideia de cidade-imagem, que é um espetáculo somente apresentado, representando falsas realidades. Sua autoria é concentrada e não distribuída, e essa cidade-imagem engana a consciência, de forma que ações/intervenções urbanas sejam facilmente aceitas, mesmo que excludentes, e sua produção torna-se mercadoria, e não espaço que contempla seus usuários cotidianos. Ao se apropriarem das cidades, seriam seus coautores responsáveis por ocultar a arte que é o desenho urbano? Aqui se defende a resposta negativa a essa pergunta. Os cidadãos conferem a legitimidade à arte que é a cidade. Qual o propósito de uma obra se ela não pode ser apreciada? Essa cidade vazia pode ser observada por poucos. Então é arte para quem? 
As cidades são "lindas" vazias, os cartões-postais causam impressão monumental, as praias parecem bucólicas. Estas são as cidades-imagem, belas para serem apreciadas de longe e nas quais um distúrbio leva a uma punição. É fato que, no momento de pandemia, com toda certeza científica, elas deveriam permanecer preservadas, para que o próprio ser humano ficasse preservado. Afinal, o ser humano é parte da cidade, e, se ele adoece, a cidade adoece e deixa de existir como vida, como movimento.

Dessa forma, ao serem apresentadas as cidades vazias pela televisão ou pela internet, o isolamento deveria ser capaz de elucidar a confirmação, para os cidadãos, de que a coautoria urbana é verídica. Ao invés de entender simplesmente que a cidade é arte quando eles não estão ali, o oposto deveria ser colocado: que a cidade sem eles não é nada além de imagem estática e morta e que eles têm total importância no espaço. Fez-se necessário, com certa urgência, propagar a mensagem que a cidade deveria ficar vazia como forma de preservar vidas. Entretanto, é fundamental que o cidadão entenda que, justamente por ele ser tão importante para a existência urbana, e como reflexão sobre a preservação de um futuro urbano vivo, ele deveria ter permanecido em casa, se pudesse. Assim, será trabalhada, a seguir, a transferência da coautoria urbana para dentro das casas durante a quarentena.

\section{A casa urbana - necessidade de ser cidade}

Ficar em casa, em quarentena, permitiu praticar sua errância, de forma mais desprendida do que no meio urbano, porque os perigos são menores. Assim, através da exploração errante da casa, uma relação antes mecânica tornou-se mais atenta. Diferentes elementos construtivos da casa, além de outros objetos e espaços, começaram a ser apropriados e, muitas vezes, convertidos para usos similares aos de elementos urbanos. 0 trabalho, a escola, a academia, o cinema, a casa de shows, tudo isso entrou nas casas, modificando as relações de seus habitantes e transformando-as por curtos períodos de tempo.

Citando Simmel (1976), Bresciani (2017) escreve que "a porta representa de maneira decisiva como o separar e o ligar são apenas dois aspectos de um mesmo e único ato", e, durante $o$ isolamento, ela representou a separação entre o mundo "perigoso" e contaminado pelo vírus e o abrigo seguro. Entretanto, aqui o foco será nos elementos da casa que são obviamente importantíssimos: a janela e a varanda, que tiveram funções muito maiores que iluminar e ventilar. Salienta-se que a janela é a necessidade primária, especialmente na pandemia de uma doença que tem como principais sintomas os problemas respiratórios. $\mathrm{Na}$ quarentena, mais do que nunca, as janelas foram o maior ponto de conexão da casa com a cidade, e a varanda tornou-se "a cidade" e foi o exterior no qual se pôde receber diretamente a luz do sol e o vento, sendo o local no qual o corpo se colocou em uma situação mais exposta e visível para outras janelas e varandas, quase como uma pequena simulação urbana.

Além dessa interferência fora-dentro, a janela/varanda permitiu o dentro-fora. Nunca se observou tanto, e essa foi, muitas vezes, a maneira de se estar mais próximo da vida urbana. Dependendo da janela/varanda, o cidadão fez análises urbanísticas e sociais sem saber, só através da observação. Percebeu o 
horário que em que situação $x$ ou $y$ acontecia diariamente, quando e onde o sol incidia mais - tanto no exterior quanto dentro da sua própria casa -, quando tinha maior ou menor fluxo de pessoas e veículos e os momentos de barulho e silêncio.

Através das relações entre o exterior 0 interior, fomentaram-se trocas e interações entre os cidadãos em suas varandas/janelas. Manifestações políticas através de panelaços, pequenos shows, vizinhos cantando "Parabéns" em coro para aniversariantes ou outras canções. Jacobs (2011) escreve que "[...] se os contatos interessantes, proveitosos e significativos entre os habitantes das cidades se limitassem à convivência na vida privada, a cidade não teria serventia" (p. 59), e estes contatos nas varandas/janelas foram a nova cidade acontecendo, o ser urbano aflorando, ou seja, sua coautoria se adaptou às novas condições, mas obviamente não sumiu. Nunca sumirá.

\section{E a favela?}

Ainda na década de 1960, Lefebvre escreve sobre a problemática do habitar, que se coloca miserável adiante da burocracia e do consumo, tocando "[...] principalmente o proletariado sem poupar outras camadas e classes sociais [...]" (2008, p. 138). Dessa forma, o autor coloca que "para aqueles que ainda duvidariam de sua existência como classe, a segregação e a miséria de seu 'habitat' designam na prática a classe operária" (ibid.). Ao serem lidas, essas palavras podem esboçar na imaginação a figura das favelas, segregadas da cidade, chamadas por muitos de "cidade informal". E a segregação cria vincos ainda maiores entre a população favelada e a população de outras regiões da cidade em meio à pandemia.

As subnotificações em favelas acionam o alarme. A classe trabalhadora precisou continuar sua vida normal e sem grandes apoios de instituições governamentais. 0 auxílio emergencial fornecido pelo governo veio de forma totalmente irregular, com aplicativos para celular que funcionavam mal ou mesmo não funcionavam, o que provocou filas enormes nos bancos, dificuldades financeiras para esses grupos, etc. Em São Paulo, segundo Rolnik, ${ }^{8}$ a questão do deslocamento para o trabalho foi determinante para o aumento de casos da Covid-19, mais do que por insalubridade das residências de regiões mais pobres.

A aceleração de casos e mortes entre pessoas negras e pobres é mais uma evidência histórica da desigualdade social e do racismo estrutural da sociedade brasileira. ${ }^{9} \mathrm{O}$ deslocamento para o trabalho, especialmente através do transporte público, também é deslocamento e transporte do vírus, fazendo com que regiões que concentram o maior número de moradores que não puderam trabalhar de casa (por fazerem parte de serviços essenciais ou por conta da necessidade de renda mínima) sejam as mais afetadas pela pandemia. Ou seja, esses cidadãos tornam-se os mais afetados porque se expõem.

Além disso, boa parte das residências em favelas não torna possível toda interação e quarentena poética descrita anteriormente. Em uma moradia bem-ventilada/iluminada e com um tamanho mínimo razoável, seja em favela ou não, existe a possibilidade mais palpável de trazer a cidade para dentro de casa e de exercer de alguma forma sua coautoria ali. Entretanto, na moradia de um cômodo localizada 
em favela, mal ventilada e iluminada e/ou que não cumpre todas as necessidades mínimas de habitabilidade, a cidade sempre foi a casa ou sua extensão, justamente por conta de suas condições. Dessa forma, torna-se quase impossível trazer essa cidade para dentro de casa com tanta poesia. Se a rua é extensão da casa, em muitos casos, a coautoria urbana é pulsante e ocorre não só através de apropriações corporais do espaço urbano, mas também com objetos, com intervenções físicas, temporárias ou não. Ou seja, é quase impossível forçar uma população que tem a rua como parte de sua casa a ficar enclausurada, porque sua própria moradia não lhe permite condições mínimas de conforto.
Dentro de parte das favelas do Rio de Janeiro, durante a quarentena, foi possível observar algumas posturas de proteção, como o uso da máscara e alguns comércios somente funcionando por delivery. Entretanto, a vida da rua aparentou estar quase "normal" em algumas regiões. Isso diz respeito não aos comércios não essenciais estarem abertos, o que envolve questões complexas, como a necessidade de renda, mas sim à apropriação da rua por pessoas que não têm um motivo ou obrigação para tal. Essa forma de coautoria - a cidade como espaço de lazer e espera - fomentou grande preocupação dentro das regiões, tanto pela disseminação rápida da doença quanto por sua gravidade que aumenta, a partir do

Figura 3 - Higienização de ruas e becos na favela Rio das Pedras, RJ

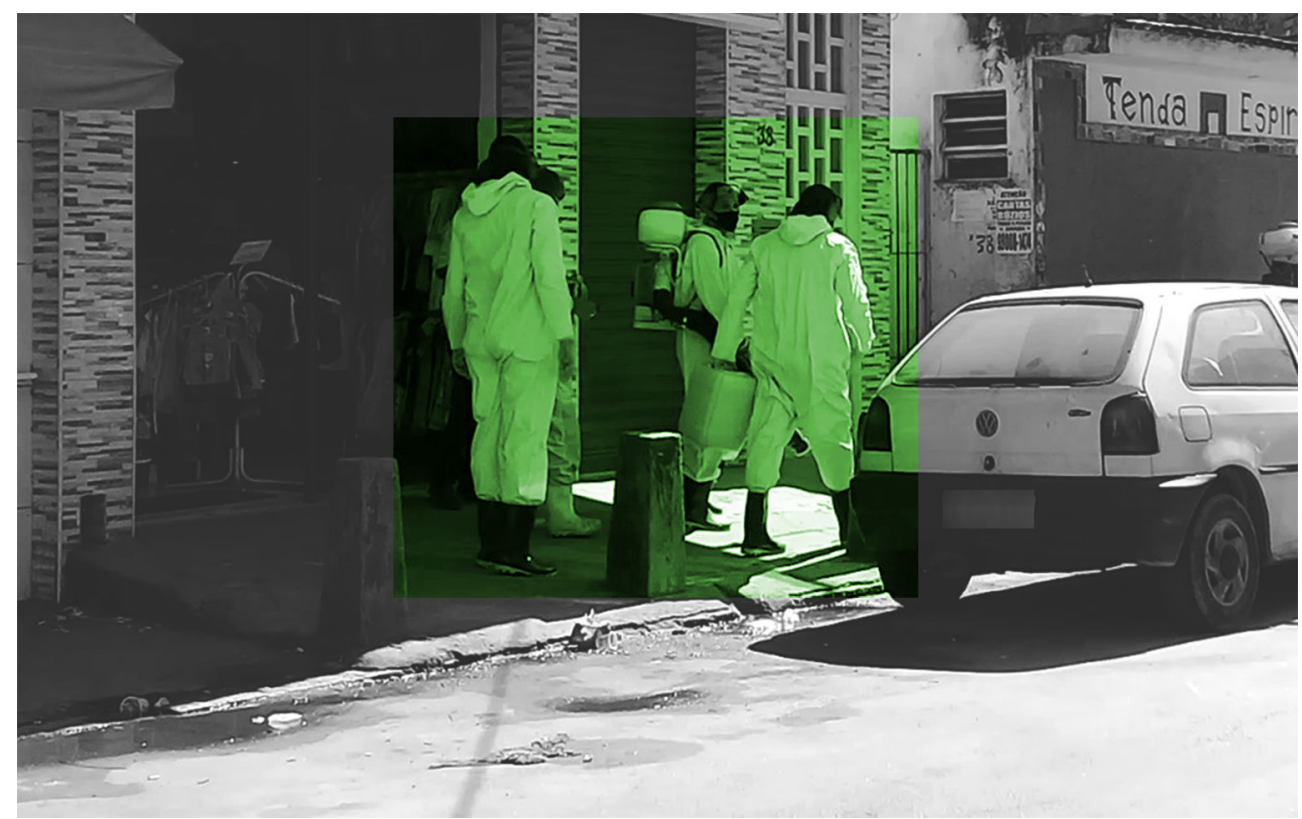

Fonte: autoral, 2020. 
momento em que falha o saneamento como um todo, impedindo que as devidas precauções sejam tomadas. Um exemplo que evidencia como é complexa essa coautoria: algumas pessoas simplesmente vão para a rua/calçada e ficam paradas ali, em determinado horário, para tomar banhos de sol ou respirarem ar fresco, porque suas casas possivelmente não oferecem esse tipo de conforto essencial. A ocupação da rua compensa a falha da casa, mas, em meio a uma pandemia, a rua torna-se justamente o lugar do perigo de contaminação e da falta de saúde. E esse perigo é quase ignorado, porque parece distante de alguma forma e menos incômodo do que passar o dia dentro da própria casa, cuja insalubridade é algo imediato e palpável.

Além de todos esses problemas internos, na favela há atuação pequena ou nula do poder público, e a vigilância contra aglomerações foi menor e muito mais complexa de ser executada, devido também à sua configuração morfológica. Como coloca Carolina Maria de Jesus (1963), "quando estou na cidade tenho a impressão de que estou na sala de visita com seus lustres de cristais, seus tapetes de viludos [sic], almofadas de sitim [sic]. E quanto estou na favela tenho a impressão de que sou um objeto fora de uso, digno de estar num quarto de despejo" (p. 33), e completa comentando que "o que está no quarto de despejo ou queima-se ou joga-se no lixo" (ibid.). Ou seja, a pandemia torna ainda mais evidente a pouca atenção às populações das favelas, sempre tomadas como o quarto de despejo das cidades.

O que se observa, então, é o levante de grupos de colaboração organizados e constituídos por pessoas das próprias favelas, para se ajudarem como for possível. Assim, grupos como a Frente de Mobilização Maré ${ }^{10}$ e a organização do Painel Unificador Covid-19 nas Favelas, ${ }^{11}$ dentre outros, fazem por suas próprias mãos um papel que deveria ser exercido pelo poder público. A favela não pode esperar. Se esperasse, já não existiria fisicamente na cidade, por conta da valorização pelo poder público das ações de remoções que existem no Rio de Janeiro desde Pereira Passos.

\section{Manifestações}

George Floyd foi assassinado por um policial branco nos Estados Unidos, provocando ondas de protestos em cidades por todo o mundo. 0 menino negro João Pedro foi morto enquanto estava em sua casa, provocando manifestações no Brasil. Notícias falsas e a disseminação de ódio chocaram as pessoas e, somadas ao movimento Black Lives Matter, fomentaram manifestações antifascistas semanais, ${ }^{12}$ levando também à derrubada ${ }^{13}$ de estátuas de figuras racistas em espaços públicos ou a suas substituições, mesmo que provisórias, por figuras representativas do movimento antirracista, intervenções artísticas, ${ }^{14}$ dentre outras ações.

Seria possível perceber, através dessa onda, o esboço de alguma revolução ou transformação mundial? O mundo viveu revoluções semelhantes na década de 1960, promoveu ocupações subversivas do espaço público com grande frequência, construiu pequenos memoriais provisórios para figuras centrais nos locais nos quais elas foram assassinadas, etc. Ou seja, algumas dessas cenas que, em 2020, foram vistas nos noticiários e vividas nas ruas já foram vistas antes. Entretanto, mesmo que seja histórica a forma de coautoria urbana construída a partir da ocupação da rua por manifestações, há um fator inédito que é 
o pano de fundo mundial de 2020: a pandemia, que torna o clamor e o protesto ainda mais potentes e urgentes. Os manifestantes, ignorando regras de isolamento social e arriscando, de alguma forma, suas vidas, fazem-no justamente porque o risco já existe há muito tempo, e as oportunidades são poucas. Ocupar a rua independentemente da possibilidade de contrair o vírus evidencia a grande necessidade do grito, da afirmação, da contestação, da mudança urgente.

Lefebvre (2008) escreve sobre direitos que abrem caminhos e definem civilizações, sendo um deles o direito à cidade, mas no sentido de vida urbana, de poder encontrar e trocar, de forma que seja permitido "[...] o uso pleno e inteiro desses momentos e locais, etc. [...]" (p. 139). Entretanto, segundo o autor, esse direito tem significados particulares para a classe operária, que aqui associo totalmente à população favelada e/ou negra. Ele coloca que essa classe, "[...] rejeitada dos centros para as periferias, despojada da cidade, expropriada assim dos melhores resultados de sua atividade [...]" (ibid.), considera o direito à cidade o meio e o objetivo ao mesmo tempo, e "[...] essa ação virtual da classe operária representa também os interesses gerais da civilização e os interesses particulares de todas as camadas sociais de "habitantes'" (ibid.). Dessa forma, percebe-se mais uma vez a força da própria população que busca seus direitos, luta por uma cidade que atenda a todos, exercitando de formas diversas a coautoria urbana, seja através de ações independentes para melhoria das favelas, seja através de manifestações políticas nas ruas.

\section{O futuro e o presente: controle e transição para reabertura}

\section{Controle e vigilância}

Quando Foucault (1987) escreve sobre uma época de peste em uma cidade no fim do século XVII, é possível perceber que os mecanismos disciplinares atuais continuam existindo, mas com nova roupagem que envolve tecnologia avançada. Ainda assim, essa cidade atingida pela pandemia, ou pela peste, como Foucault coloca, divide-se de forma maciça e binária, recorrendo "[...] a separações múltiplas, a distribuições individualizantes, a uma organização aprofundada das vigilâncias e dos controles, a uma intensificação e ramificação do poder" (1987, p. 222). Portanto, duas formas de tentativa de domínio são trazidas aqui: a primeira diz respeito ao governo em si, que influencia, desde a recomendação do uso de máscaras (ou da oposição à recomendação), até a proposta de controle do espaço público, como o aplicativo para uso da praia no Rio de Janeiro; ${ }^{15}$ a segunda forma diz respeito ao poder aquisitivo de determinadas camadas da população, que são as que podem acessar drive-ins (por serem economicamente poderosas e/ou por possuírem veículos próprios), como será colocado adiante.

A vigilância não só poda o comportamento do ser no meio urbano como faz com que ele se ausente desse meio, o que construiu para muitos o isolamento opcional muito antes da pandemia, pelo receio da exposição ante a vigilância presente em cada lugar. Ao mesmo tempo que a vigilância provocou esse 
isolamento pelas pessoas não quererem ou saberem lidar com ela, seu planejamento e onipresença tornaram-se "[...] uma evidência na vida cotidiana" e passaram a ser aceitos "como antídoto à violência diversificada e sempre à espreita [...]" (Bresciani, 2017, p. 110). Essa colocação expõe o quão contrastantes são as consequências dessa vigilância, que geram situações diversas e constroem novas formas de percepção da vida cotidiana urbana.

No momento de pandemia, com o comportamento de boa parte da população em ignorar o isolamento, a vigilância fez-se necessária e, ao mesmo tempo, tornou-se ferramenta de controle. Foucault (1987) escreve que "a cidade pestilenta [...], a cidade imobilizada no funcionamento de um poder extensivo que age de maneira diversa sobre todos os corpos individuais - é a utopia da cidade perfeitamente governada" (p. 222), o que pode esboçar como o controle e a vigilância permeiam diversas esferas da pandemia e do momento de reabertura, em que "a relação de cada um com sua doença e sua morte passa pelas instâncias do poder, pelo registro que delas é feito, pelas decisões que elas tomam" (ibid., p. 220). Rondas policiais, blitz, multas, drones como vigilância contra aglomerações e o disk-aglomeração, para denúncias no Rio de Janeiro, foram algumas das formas de controle utilizadas para tentar manter a população em casa e reduzir o número de contágios da Covid-19. Entretanto, surge a preocupação sobre o uso futuro desses instrumentos de controle.

Foucault (ibid.) escreve que "a disciplina é uma anatomia política do detalhe" (p. 166), e sabe-se que, na pandemia, o corpo está criando novas disciplinas. Para alguns grupos, existem poucas possibilidades de ociosidade no comportamento, tendo em vista que a preocupação com detalhes é colocada, e até mesmo o comportamento do outro é fiscalizado para preservar a própria vida. Além disso, para que a cidade possa ser praticada, a articulação corpo-objeto de Foucault (ibid.) faz-se presente, como, por exemplo, através do uso de novos elementos, como a máscara, o álcool em gel, as marcações no chão dos lugares, apoiando o afastamento, correspondendo também a uma tática disciplinar que, como o autor escreve, conecta o singular e múltiplo. Certeau (2014) escreve que instrumentos como o cacetete e as algemas, que são físicos, "[...] compõem uma série de objetos destinados a gravar força da lei sobre o seu súdito [...]" (p. 211). Entretanto, uma outra preocupação é com os instrumentos não físicos, que geralmente existem antes dos físicos, como, por exemplo, funcionavam, nas últimas décadas do século XIX, os Códigos de Postura Municipais, que não só controlavam o comportamento da população do Rio de Janeiro, como especialmente atuavam como forma de reafirmação da separação da elite carioca. ${ }^{16}$ As leis invisíveis e não oficiais são instrumentos ainda mais fortes do que as oficiais, vindas de construções culturais ao longo da história. A ordem pública, segundo Jacobs (2011), "é mantida fundamentalmente pela rede intrincada, quase inconsciente, de controles e padrões de comportamento espontâneos presentes em meio ao próprio povo e por ele aplicados" (p. 32). Dessa forma, o controle assegura que a cidade sacralizada assim permaneça, podendo ser apropriada somente por determinados grupos, e, quando há o inesperado, ele é considerado “[...] uma profanação espacial, 'um pecado' que merece ser punido ou prevenido, para que a imagem continue 'bela e estática', limitando, 
educando e reparando o corpo que ali existe" (Rocha, 2019, p. 51). Portanto, o controle - para alguns - sempre pairou e gerou conflitos urbanos. No momento de pandemia, o controle é necessário, mas como será o futuro das cidades ante esse controle?

Os instrumentos de punição e prevenção do uso da cidade considerado inapropriado pelas autoridades estão cada vez mais sofisticados e, portanto, eficazes. Esse fato pode ser uma grande ameaça à ideia de coautoria urbana quando esta subverte o uso positivamente, transformando-o conforme as necessidades do momento daquele cidadão. Pode ser uma ameaça ao espontâneo que traz vida e que, consequentemente, pode trazer segurança aos espaços públicos. Ao mesmo tempo, ainda com todo esse controle existente na pandemia, muitos permaneceram apropriando-se dos espaços públicos, sem preocupação com punições. Seria essa uma evidência de que, no futuro, será possível ir contra esse sistema de controle e vigilância urbanos?

\section{Panorama geral da reabertura}

A partir da busca pela readequação de usos nas cidades, cresceram, ao redor do mundo, formas de ocupação urbana há muito defendidas por alguns urbanistas. O Reino Unido fez incentivos para o uso da bicicleta - meio de transporte que facilita o distanciamento social, prevenindo contágios pelo vírus. Cidades europeias promoveram o fechamento de vias de carros para uso de pedestres e ocupações mais permanentes, além da construção de parklets em Nova York, e foram demarcados espaços para grupos nos parques, para assegurar o distanciamento social. ${ }^{17}$
No Brasil, a reabertura veio através de rodízios de trabalho, "regras de ouro" da prefeitura no Rio de Janeiro, capacidade dos estabelecimentos reduzida, etc. Ainda assim, os cuidados foram pouco respeitados. A praia, por exemplo, mesmo quando proibida para banho de mar e/ou ocupação da faixa de areia, recebia público que quebrava a lei, muitos inclusive sem máscara. A tentativa de implementação do projeto de organização das praias do Rio de Janeiro por cercadinhos a serem reservados mediante aplicativo veio como resposta e tentativa de controle do governo, mas foi tão fora da realidade da cidade que teve seu fracasso eminente, mesmo antes de efetivamente ser implementado, porque se sabe que o espaço da praia é espaço de sociabilização, está na alma carioca.

Além disso, com a crise econômica gerada pela pandemia, diversos estabelecimentos fecharam suas portas, levando estado de abandono aos seus respectivos contextos urbanos, o que, apesar da retomada geral, torna alguns espaços mais vazios e até mesmo perigosos. As imagens chocantes de aglomeração nas ruas do Brás, ${ }^{18}$ em São Paulo, no primeiro dia de reabertura, mostram também a necessidade do trabalho, que se sobrepõe à preocupação com a pandemia, como colocado anteriormente.

Sabe-se que a continuidade do período de quarentena germinou novas situações e hábitos na cidade. Os drive-ins - sucesso em décadas passadas - retornaram repaginados, como solução à impossibilidade de aglomeração, tendo limites de veículos e de pessoas por veículos, o que tornou a lotação máxima muito pequena, com reserva feita através de agendamento por aplicativo para idas ao banheiro, buzinas e faróis como aplausos. E a repaginação foi além do cinema, esparramando-se para 
outras esferas do entretenimento, como mega shows (alguns em estádios), exposição de arte (drive-thru que oferece carro para os que não têm e com tempo máximo de parada em frente a uma obra) e até mesmo o tradicional circo (com área vip para carros ficarem mais perto do picadeiro), além de megacerimônias de casamento drive-in. ${ }^{19}$ Boa parte desses drive-ins surge como solução para diversão da população, mantendo a prevenção, a saúde e o cuidado contra a Covid-19. Entretanto, sabe-se que essa forma de diversão é pouco acessível à massa já que, mesmo sendo um entretenimento "na rua", é necessário ter um carro, além de conseguir bancar o custo do ingresso.

Crescem, portanto, algumas preocupações que vão além da pandemia em si, como o esvaziamento dos espaços públicos das cidades, bem como a rápida expansão do abismo entre as classes sociais. Uma situação leva à outra e ainda fomenta a preocupação com o discurso higienista que, ao longo da história, teve papel fundamental na composição da desigualdade social e racial. Mesmo que, por toda a cidade, as ruas tenham ficado cheias após a reabertura, como próximo aos bares do Leblon ou da Barra da Tijuca - rendendo "carteiradas" 20 e humilhações por parte dos cidadãos de classes mais favorecidas, as ruas cheias da favela, bem como seus bailes, foram considerados os grandes "disseminadores da doença" aos olhos de determinados grupos da sociedade. Claro que, em momento de pandemia, é errado a aglomeração em qualquer lugar que seja, mas a preocupação é que essas situações surjam como oportunidades para legitimação de um discurso de remoções. Além disso, muitos dos que trabalham nesses estabelecimentos abarrotados em bairros nobres são os moradores de regiões mais pobres, como favelas e subúrbios, e podem tornar-se vetores da doença, enquanto as formas de apropriação urbana de seus clientes, bebendo e interagindo na rua, sem máscara e distanciamento, continuam normais.

\section{Novas camadas coautoras}

Com a reabertura, a organização dos grupos coautores permanece, com acréscimo de novas camadas gerais.

Os imunes: nessa camada, os coautores são cidadãos que podem ter se isolado previamente ou não, contaminaram-se ou acreditam terem sido contaminados com a doença, conseguiram a cura e acreditam que estejam imunes. Por isso, sua apropriação urbana voltou a ser o que sempre foi, totalmente despreocupada, com pouco ou nenhum cuidado.

Os cautelosos: nessa camada, seus coautores puderam e/ou quiseram permanecer em quarentena, mas, com a reabertura, com o tempo de isolamento, por terem sido contaminados e/ou por acreditarem terem sido contaminados com a doença, sentiram alguma liberdade e/ ou necessidade de fazerem pequenas saídas e apropriações tímidas e cuidadosas da cidade.

\section{Considerações finais}

Sobre as epidemias do século XIX na Europa, Bresciani (2017) explica que "a cidade passava a ser pensada como espaço que, transformado pela técnica, tornar-se-ia um meio ideal para formar pessoas saudáveis, moralizadas e trabalhadoras" (p. 121), o que remete à colocação de Certeau (2014), na qual defende que 
“o corpo se repara. Educa-se. Até mesmo se fabrica" (p. 213). A cidade pós-epidemias (ou pandemias) pode trazer duas vertentes nas suas construções: pode ser um instrumento de controle dos cidadãos, fabricando-os, mas também pode ser um instrumento de transformações positivas do espaço urbano, como colocado previamente. Portanto, é questionável se, no pós-pandemia, existirá uma conversão positiva da coautoria urbana através da adoção de medidas inovadoras e há muito desejadas, como a prioridade da bicicleta, além de uma movimentação contra o controle excludente e agressivo da cidade.

Bresciani (2017) comenta que "[...] entre os objetivos de melhorar as condições de vida urbana esteve sempre presente civilizar seres considerados 'semibárbaros'" (p. 120). Assim, entende-se que "civilizar" significa impor seus próprios costumes, excluindo qualquer cultura genuína desses seres, e melhorar a vida urbana significa retirá-los de lugares visados para o capital, como forma de "limpeza" urbana. Esses objetivos permanecem, mas, durante a pandemia, são apaziguados e se convertem em ignorância dos problemas. Tentativas mínimas de preocupação com a população favelada são efetivadas, como, por exemplo, através dos hotéis para idosos, ${ }^{21}$ mas estão muito distantes de ser o que a população realmente precisa. Na industrialização, para Lefebvre (2008), "[...] a classe operária sofre as consequências da explosão das antigas morfologias. Ela é vítima de uma segregação, estratégia de classe permitida por essa explosão. Tal é a forma atual da situação negativa do proletariado" (p. 138), e pode-se afirmar o mesmo no momento de pandemia, no qual, através das transformações provocadas por ela, a luta de classes torna-se ainda mais evidente em todas as áreas, como, por exemplo, na divisão entre os que puderam trabalhar de casa e os que precisaram sair - especialmente utilizando o transporte público -, ou seja, classe operária menos favorecida. Nas apropriações urbanas, isso também se tornou evidente, seja durante o período de isolamento, seja na reabertura. A insalubridade e a falta de saneamento nas favelas também se tornaram situações latentes e urgentes. Por isso, obviamente deve-se fomentar e levantar uma discussão entre arquitetos e urbanistas, governantes, dentre outros profissionais, somados à própria população, que é a maior interessada. Essa discussão deve ser intensa e não permanecer em artigos e mesas-redondas, sendo desenvolvida e levando à construção e à execução de políticas urbanas realmente efetivas que contemplem os cidadãos mais necessitados, sem exclusão ou remoção. Obras públicas efetivas, melhorias e fornecimento de infraestrutura, habitações dignas, além da consultoria técnica, que deveria ser um serviço público.

Lefebvre (ibid.) explica sobre o ideal da planificação, ou seja, do equilíbrio entre classes e poderes, como forma de se pensar em uma urbanização realmente efetiva e que atenda às demandas sociais, além da necessidade de uma ciência da cidade. Dessa forma, para o autor, "só se a classe operária e seus mandatários políticos se encarregarem da planificação é que será possível modificar profundamente a vida social [...]" (p. 139). Entretanto, como pode ocorrer esse investimento da/na classe operária em um período de tanta desinformação e fake news, no qual o conhecimento dos livros se vê confrontado por "conhecimentos" compartilhados em aplicativos? E como é possível a planificação a partir da classe operária se ela se vê a cada dia mais 
abafada, excluída e exterminada dentro das políticas urbanas? Acredita-se que a planificação seja possível através das microrresistências que afloram na cidade e que, espera-se, aflorem na cidade pós-pandemia, exatamente como Jacobs (2011) escreve: "aparentemente despretensiosos, despropositados e aleatórios, os contatos nas ruas constituem a pequena mudança a partir da qual pode florescer a vida pública exuberante da cidade" (p. 78).

Além disso, com a quarentena dos que puderam fazê-la, percebeu-se a valorização da cidade a partir da sua "perda", como a falta de atividades cotidianas, de encontros entre pessoas, de ver vida. Alguns sentiram falta até mesmo das situações mais penosas do cotidiano urbano, como o momento no transporte público. Dessa forma, complementando essa ideia de futuro, assim como a relação mecânica com a casa se tornou mais atenta e aberta, o anseio pela prática coautora da cidade pode tornar-se também mais atenta após a pandemia. 0 medo do contágio somado a certo trauma provavelmente ainda irá pairar intensamente no ar da cidade, mas o alívio do retorno à interação, à visão de lugares tão conhecidos e que estiveram tão distantes pode alimentar uma relação mais profunda e atenta ao meio urbano. Quando Bresciani (2017) escreve sobre o pós-Segunda Guerra, ela explica que, ao mesmo tempo que pairavam mecanismos de controle, as cidades destruídas foram reconstruídas e novas cidades foram planejadas. Sabe-se que pandemias revolucionaram sociedades historicamente, assim como as guerras. Entretanto, enquanto as cidades físicas do pós-guerra foram reconstruídas para, posteriormente ou paralelamente, ser reconstruída a sociedade, na pandemia ocorre quase o oposto: a cidade é reconstruída a partir da sociedade.

\section{[I] https://orcid.org/0000-0002-0831-0842}

Universidade Federal do Rio de Janeiro, Faculdade de Arquitetura e Urbanismo, Programa de Pós-Graduação em Urbanismo, Laboratório de Intervenções Temporárias e Urbanismo Tático. Rio de Janeiro, RJ/Brasil.

gaqrocha@gmail.com 


\section{Notas}

(1) A autora pôde permanecer em home office ao longo da quarentena e é moradora de favela.

(2) As entrevistas foram feitas no início de maio de 2020.

(3) Os nomes das pessoas entrevistadas foram omitidos para preservá-las.

(4) Os trabalhadores da linha de frente da saúde, como enfermeiros e médicos, são aqui considerados um caso à parte, porque, além da preocupação com o deslocamento, eles têm a preocupação dentro de seu próprio trabalho; boa parte deles permanecendo isolada de sua família. Portanto, o cotidiano deles é completamente diferente dos grupos descritos.

(5) Vários cidadãos, por exemplo, ficaram sem condições de pagar aluguel em São Paulo e passaram a morar em uma ocupação nas margens da Rodovia dos Imigrantes. Mais informações em Barcellos e Tavolieri (2020).

(6) Para maiores informações sobre o auxílio emergencial, consultar em <https://auxilio.caixa.gov. br/\#/inicio>. Acesso em: 24 ago 2020.

(7) Muitos ambulantes aproveitaram as aglomerações das filas dos bancos para tentarem vender algum produto.

(8) Raquel Rolnik lidera a pesquisa, feita em parceria com o Instituto Pólis, cruzando dados de áreas com maior concentração de hospitalizações por Covid-19 e dados da companhia de transportes São Paulo (SPTrans). Para mais informações, ver Ziegler (2020).

(9) Para melhor compreensão sobre o assunto, ver Nascimento (2016).

(10) Ver site da Frente de Mobilização Maré. Disponível em: https://www.frentemare.com/. Acesso em: 25 ago 2020.

(11) Mais informações no site do Painel Unificador Covid-19 nas Favelas. Disponível em: https:// experience.arcgis.com/experience/8b055bf091b742bca021221e8ca73cd7/. Acesso em: 25 ago 2020.

(12) Ver Pires e Magri (2020).

(13) Ver Corrêa (2020).

(14) A frase Black Lives Matter foi pintada em grande escala na 16th street, em Washington, em meio às manifestações contra o racismo, e a prefeitura modificou seu nome, batizando-a com a citada frase. Mais informações em O Estado de S.Paulo (2020).

(15) Ver Extra (2020).

(16) Ver Distrito Federal (1984).

(17) Ver AFP e Ansa (2020) e UOL (2020).

(18) Ver Vieira (2020).

(19) Ver Fantástico (2020).

(20) Ver G1 Rio (2020).

(21) Ver Campos (2020). 


\section{Referências}

AFP; ANSA (2020). Diante da pandemia, a Europa sobe na bicicleta. Disponível em: https://oglobo.globo. com/mundo/diante-da-pandemia-europa-sobe-na-bicicleta-24426403. Acesso em: 25 ago 2020.

BARCELLOS, C.; TAVOLIERI, N. (2020). Crise causada pela pandemia leva trabalhadores sem dinheiro para o aluguel para ocupações. Disponível em: https://g1.globo.com/fantastico/noticia/2020/08/23/ crise-causada-pela-pandemia-leva-trabalhadores-sem-dinheiro-para-o-aluguel-para-ocupacoes. ghtml. Acesso em: 25 ago 2020.

BRESCIANI, M. S. (2017). "Dimensões do estar no mundo/cidades: o público, o privado, o íntimo". In: JACQUES, P. B.; BRITTO, F. D. (orgs.). Corpocidade: gestos urbanos. Salvador, Edufba, pp.102-149.

CAMPOS, A. C. (2020). Rio: idosos de comunidades podem ficar em hotéis para evitar covid-19. Disponível em: https://agenciabrasil.ebc.com.br/saude/noticia/2020-03/rio-idosos-de-comunidadespodem-ficar-em-hoteis-para-evitar-covid-19. Acesso em: 24 ago 2020.

CERTEAU, M. D. (2014). A invenção do cotidiano: 1. Artes de fazer. Petrópolis, Vozes.

CORRÊA, C. (2020). Derrubada de estátuas de figuras ligadas à escravidão provoca debate sobre reescrever o passado. Disponível em: https://www.correiodopovo.com.br/especial/derrubadade-est\%C3\%A1tuas-de-figuras-ligadas-\%C3\%A0-escravid\%C3\%A3o-provoca-debate-sobrereescrever-o-passado-1.441932. Acesso em: 24 ago 2020.

DISTRITO FEDERAL (BRASIL) (1894). Código de posturas: leis, decretos, editaes e soluções da Intendencia Municipal do Districto Federal. Rio de Janeiro, Typ. Mont'alverne. Disponível em: http://www2. senado.leg.br/bdsf/handle/id/224185. Acesso em: 25 ago 2020.

EXTRA (2020). Reserva de cercadinho na praia por app será gratuita: primeiro teste com áreas demarcadas deve acontecer neste domingo. Disponível em: https://extra.globo.com/noticias/rio/ reserva-de-cercadinho-na-praia-por-app-sera-gratuita-primeiro-teste-com-areas-demarcadasdeve-acontecer-neste-domingo-rv1-1-24580873.html. Acesso em: 2 set 2020.

FANTÁSTICO (2020). Casamento drive-in: os efeitos da pandemia em uma das datas mais importantes para casais. Disponível em: https://g1.globo.com/fantastico/noticia/2020/08/16/casamentodrive-in-os-efeitos-da-pandemia-em-uma-das-datas-mais-importantes-para-casais.ghtml . Acesso em: 24 ago 2020.

FOUCAULT, M. (1987). Vigiar e punir. Petrópolis, Vozes.

G1 RIO (2020). Mulher que discutiu com fiscal e disse que marido era melhor por ser "engenheiro civil" é demitida. Disponível em: https://g1.globo.com/rj/rio-de-janeiro/noticia/2020/07/06/mulherflagrada-humilhando-fiscal-em-reportagem-do-fantastico-e-demitida.ghtml . Acesso em: 24 ago 2020.

JACOBS, J. (2011). Morte e vida de grandes cidades. São Paulo, WMF Martins Fontes.

JESUS, C. M. (1963). Quarto de despejo. Edição Popular.

LEFEBVRE, H. (2008). O direito à cidade. São Paulo, Centauro.

NASCIMENTO, A. (2016). O genocídio do negro brasileiro: processo de um racismo mascarado. São Paulo, Perspectivas. 
O ESTADO DE S.PAULO (2020). Prefeitura muda nome de rua em frente à Casa Branca para Black Lives Matter. Disponível em: https://internacional.estadao.com.br/noticias/geral,prefeitura-mudanome-de-rua-em-frente-a-casa-branca-para-black-lives-matter,70003326184. Acesso em: 24 ago 2020.

PIRES, B.; MAGRI, D. (2020). Torcidas antifascistas assumem linha de frente da mobilização contra Bolsonaro e atraem oposição. Disponível em: https://brasil.elpais.com/esportes/2020-06-01/ torcidas-antifascistas-assumem-linha-de-frente-da-mobilizacao-contra-bolsonaro-e-atraemoposicao.html. Acesso em: 25 ago 2020.

ROCHA, G. (2018). Coautoria urbana: conflitos entre corpo e cidade-imagem. V!RUS. São Carlos, n. 17 [online]. Disponível em: <http://www.nomads.usp.br/virus/virus17/?sec=4\&item=7\&lang=pt>. Acesso em: 21 maio 2020.

(2019). Coautoria urbana: a funcionária, o produtor e o camelô. Dissertação de mestrado. Rio de Janeiro, Universidade Federal do Rio de Janeiro.

SIMMEL, G. (1976). "A metrópole e a vida mental”. In: VELHO, O. G. (org.). O fenômeno urbano. Rio de Janeiro, Zahar.

UOL (2020). Parque de NY faz marcações no chão para garantir isolamento social; veja. Disponível em: https://noticias.uol.com.br/internacional/ultimas-noticias/2020/05/17/parque-de-ny-fazmarcacoes-no-chao-para-garantir-isolamento-social-veja.htm. Acesso em: 25 ago 2020.

VIEIRA, B. M. (2020). Cidade de SP registra filas em lojas, aglomerações nas ruas e transporte público lotado no 1o dia de reabertura do comércio. Disponível em: https://g1.globo.com/sp/sao-paulo/ noticia/2020/06/10/cidade-de-sp-registra-filas-em-lojas-aglomeracoes-nas-ruas-e-transportepublico-lotado-no-1o-dia-de-reabertura-do-comercio.ghtml. Acesso em: 24 ago 2020.

ZIEGLER, M. F. (2020). Deslocamento para o trabalho pode explicar concentração de casos de COVID-19 em alguns bairros de SP. Disponível em: https://agencia.fapesp.br/deslocamento-para-otrabalho-pode-explicar-concentracao-de-casos-de-covid-19-em-alguns-bairros-de-sp/33625/. Acesso em: 25 ago 2020.

Texto recebido em 7/set/2020

Texto aprovado em 10/mar/2021 